\title{
Use of space in two neighboring groups of the howler monkey Alouatta palliata mexicana (Primates: Atelidae): overlap and home range size
}

\author{
Paulo César Quintana-Morales ${ }^{1 *}$, Jorge E. Morales-Mavil' ${ }^{1}$, Mateo Escobar-Aliaga', and Rocio Bravo-Xicotencatl \\ ${ }^{1}$ Laboratorio de Biología de la Conducta, Instituto de Neuroetología, Universidad Veracruzana, Av. Luis Castelazo Ayala s/n, \\ Colonia Industrial Ánimas, CP. 91190, Xalapa. Veracruz, México. Email: pquintana@uv.mx (PCQM), jormorales@uv.mx \\ (JEMV), nauyuca@hotmail.com (MEA), chiyta@yahoo.com.mx (RBX). \\ * Corresponding author
}

The interaction between primate groups and the dynamics involved in the use of space are important factors affecting both competition for resources and intergroup dominance. In the present study we analyzed the differences in home range overlap and intergroup size, as well as the diversity of tree species within the home range, the Value Index for the key tree species, and the daily activity pattern of two neighboring groups of the howler monkey Alouatta palliata. From March 2002 to June 2003, the behavior and location of two groups of monkeys (G1, two adult males, four adult females and four infants; G2, six adult males, five adult females, one juvenile and three infants) were recorded in the same forest patch at Los Tuxtlas Biosphere Reserve, Veracruz, Mexico. Using the Minimum Convex Polygon (100 \%), grid (100 m), and Kernel (adapted and fixed) methods, as well as transect sampling, significant differences $\left(\mathrm{F}_{1,20}=14.45, P=0.001\right)$ were found in the home range size of the groups, being greater in G2. The habitat in the $\mathrm{G} 2$ home range had greater richness and diversity of tree species, as well as a higher Importance Value Index for the key tree species (Ficus spp.) included in the howler monkey diet. On the other hand, significant differences between groups (Mann-Whitney $U=38, P<0.05$ ) were found only as regards locomotion behavior, likely due to a behavioral adaptation to optimize food resource use or search. The two groups displayed a similar use of food resources; however, there was a slight overlap in the home range between both groups with no direct aggression, likely because their habitat included sufficient space and food. Our data suggest that the reduced overlap may vary between neighboring groups because of factors such as group size. However, groups could weigh various factors to avoid home-range overlap.

La interacción entre grupos vecinos de primates y la dinámica en el uso del espacio son factores importantes durante la competencia por los recursos y la dominancia intergrupal. En este trabajo analizamos las diferencias intergrupales con relación al tamaño y traslape del ámbito hogareño así como la diversidad de especies arbóreas, el Índice de Valor de Importancia de especies clave y el patrón diario de actividad de dos grupos vecinos de monos aulladores Alouatta palliata mexicana. De marzo 2002 a junio 2003 registramos la conducta y las ubicaciones de dos grupos de monos (formados, G1 por 2 machos adultos, 4 hembras adultas y 4 infantes, y G2 por 6 machos adultos, 5 hembras adultas, 1 joven y 3 infantes) en un mismo fragmento en la Reserva de la Biósfera Los Tuxtlas, Los Tuxtlas, Veracruz, México. Aplicando los métodos de Polígono Mínimo Convexo (100\%), Rejillas (100 m), y Kernel (adaptado y fijo) así como un muestreo por transectos se encontraron diferencias significativas $\left(F_{1,20}=14.45, P=0.001\right)$ en el ámbito hogareño de los grupos, siendo mayor el de G2. El hábitat en el ámbito hogareño del G2 tuvo una mayor riqueza y diversidad de especies arbóreas así como un valor más elevado en el Índice de Valor de Importancia de especies clave (Ficus spp.) en la dieta de los monos aulladores. Por otra parte, se encontraron diferencias significativas (Mann-Whitney $\mathrm{U}=38, P<0.05$ ) sólo en la conducta de locomoción, posiblemente debido a un ajuste conductual para optimizar el aprovechamiento o la búsqueda de recursos alimentarios. Los recursos alimentarios utilizados por los dos grupos fueron similares; sin embargo, se registró un reducido traslape del ámbito hogareño entre los grupos y ningún tipo de agresión directa, lo cual puede deberse a que encuentran suficiente espacio y alimento en el hábitat. Nuestros datos sugieren que el reducido traslape puede variar entre grupos vecinos a causa de factores como el tamaño del grupo. Sin embargo, es posible que los grupos decidan ponderar diversos factores a fin de evitar los traslapes de ámbito hogareño.

Key words: competition; howler monkey; intergroup distance; overlapping home range; spatial interactions.

C 2017 Asociación Mexicana de Mastozoología, www.mastozoologiamexicana.org

\section{Introduction}

The use of space is a key component of the ecological niche for all animal species (Lopez-Darias et al. 2012). One of the essential parameters to quantify the use of space is the home range (Börger et al. 2008). The size and the internal dynamics of the home range (HR) are influenced by the environmental, biological, and social factors of each species. In the case of primates, key factors as group biomass (Campos et al. 2014), group size (Shaffer 2014), habitat quality (Campera et al. 2014), vegetation type (Pebsworth et al. 2012), seasonality (Pyritz et al. 2011), and population density (Glessner and Britt 2005).
Unlike a territory, where individuals must invest time and energy to protect it (Kodric-Brown 1978; Amsler and Brown 2010), the HR can be shared either partially or totally. In this sense, it is argued that the level of HR overlap in various primate species depends on both the conditions of the habitat and the physical characteristics of the species (Pearce et al. 2013). In the Neotropics, the howler monkey (Alouatta spp.) is considered a non-territorial species (Milton 1980; Hopkins 2013) because the home range frequently overlaps. Hopkins (2013) has pointed out that the separation between groups of howler monkeys seem to be influenced by the hierarchical status of neighboring 
groups. However, he makes no reference to the influence of habitat quality, access to resources and their availability.

The objective of this work was to determine the size of the home range and the extent of the spatial interaction between two groups of howler monkeys, based on the overlap of their respective HR. We explored whether the tree species richness and diversity, and the size of the groups of monkeys, are associated with the use of space by two neighboring groups of howler monkeys that inhabit a fragmented landscape in Los Tuxtlas Biosphere Reserve, Veracruz, Mexico.

\section{Materials and Methods}

Study area and subjects. The study area is located in the region of Los Tuxtlas, Veracruz, Mexico. This area is fragmented and disturbed, with patches of primary vegetation within a matrix of agricultural and livestock areas (Mendoza et al. 2005; Solórzano-García et al. 2012). The patch inhabited by monkeys is an irregular-shaped polygon encompassing 100 ha approximately, with connections that enable the displacement of groups to other forested areas of similar size. It is located near the community of Montepio $\left(18.63306^{\circ}\right.$ to $18.64778^{\circ} \mathrm{N}$ and -95.09556 to $-95.07861^{\circ} \mathrm{W}$; Figure 1), within Los Tuxtlas Biosphere Reserve, Veracruz, Mexico. The vegetation is evergreen forest with various degrees of disturbance. The canopy species include Lonchocarpus cruentus, Dussia mexicana, Nectandra ambigens, Brosimum alicastrum, Ficus yoponensis, Ficus tecolutensis, Pouteria sapota, Spondias radlkoferi and Bursera simaruba, among others (Castillo-Campos and Laborde 2004). The climate is warm and humid, with a dry season from March to May and a rainy season from June to February. Rainfall ranges from 3,500 to $4,000 \mathrm{~mm}$ per year $(60 \mathrm{~mm}$ in the driest month), and the mean annual temperature is above $22^{\circ} \mathrm{C}$ (Soto 2004). Whithin this patch, Cristobal-Azkarate and Arroyo-Rodríguez (2007) estimated the presence of seven groups of Alouatta palliata mexicana; for this work, two neighboring and potentially interacting groups were selected, to obtain behavioral records. At the start of the study, the groups selected were the following: group 1 (G1), 10 individuals (2 adult males, four adult females and four infants); group 2 (G2), 15 individuals (six adult males, five adult females, a young and three infants). The number of adults did not vary throughout the recording period; however, new infants were born, so that at the end of the recording period, G1 and G2 had four and three infants, respectively. The sex and age of individuals was determined based on the classifications of Clarke (1990) and Domingo-Balcells and Veà-Varo (2009).

Location of groups and behavioral records. The location of each group was recorded between March 2002 and June 2003 using a portable Global Positioning System (Garmin model V plus). Groups were recorded through sightings in the morning (07:00 to 13:00 h) and evening (13:00 to 18:00 h) which were alternated during 55 and 67 days (G1 and G2, respectively). The difference in the recording days between the two groups was due to the fact that G1 stabilized its HR in February 2003, while G2 did it in March; hence, the latter required a greater number of days of follow-up and a larger number of locations for the estimates. On aver-

95.12306

95.10417

95.08528

95.06369

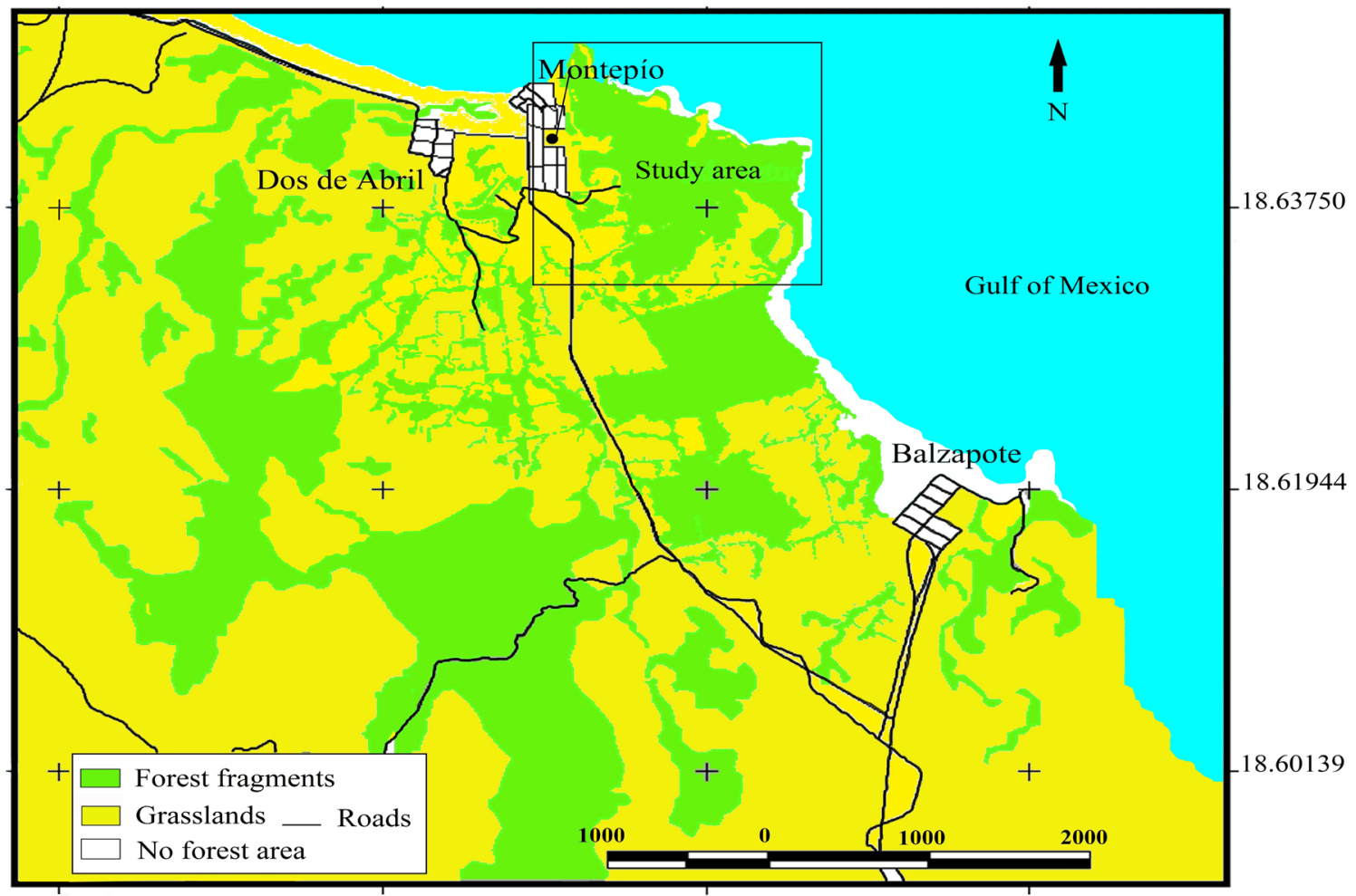

Figure 1. Location of the study area (box) where various groups of the howler monkey, Alouatta palliata, coexist in the region of Los Tuxtlas, Veracruz, Mexico, on the Gulf of Mexico coast. 
Table 1. Estimates of the home range of two groups ( $\mathrm{G} 1$ and $\mathrm{G} 2$ ) of the howling monkey, Alouatta palliata, in Veracruz, Mexico, based on various methods and indicators of overlap between groups.

\begin{tabular}{lccc}
\hline Method & $\begin{array}{c}\text { G1 } \\
\text { (Home range } \\
\text { ha) }\end{array}$ & $\begin{array}{c}\text { G2 } \\
\text { Percent home range shared } \\
\text { by G1 and G2 (average) }\end{array}$ \\
\hline Minimum Convex Polygon & 9.4 & 19.7 & 0.0 \\
100 m grids & 10.0 & 21.0 & 25.0 \\
Kernel, adapted & 7.8 & 23.3 & 0.0 \\
Kernel, fixed & 7.0 & 20.0 & 4.4 \\
\hline
\end{tabular}

age, five days of location records were considered for each group per month.

After recording the location and identity of the group found, the daily activity pattern was recorded by a continuous record over one hour in a focal animal sampling (Altmann 1974; Martin and Bateson 1993) of adult individuals of both sexes. The groups were compared in terms of the proportion of episodes dedicated to each behavior, using a Mann-Whitney $U$ test to compare the percentage of episodes of each behavior per month as the dependent variable. The behaviors observed were: rest, when the individual maintained a given position, either sitting, lying or hanging, without performing any other activity. Feeding, when the animal consumed or manipulated a food item (particularly leaves, flowers or fruits). Locomotion, when the animal moved at least a length equivalent to its body size along varying distances not beyond the tree or set of trees where the group was seated. Trip, when the animal moved over a distance that exceeded the set of trees where the rest of the group was located. Social behavior, when one individual interacted with others within the group. This category included aggressive behaviors such as biting, shoving, slapping, showing teeth, chasing, fighting; affiliative behaviors, when subjects interacted closely with another individual displaying a non-aggressive behavior; or sexual behaviors, including sexual intercourse and courtship.

Calculation of the home range (HR). The HR of each group was estimated using three methods, so that the size of the HR could be comparable with other studies: 1) the Minimum Convex Polygon (PMC) method, at $100 \%$ (Kernohan et al. 2001); 2) the grid method (100 x $100 \mathrm{~m})$; and 3) the adaptive and fixed $95 \%$ Kernel method (Estrada 1984; Worton 1989; Dunn et al. 2009). The data for calculating the HR were the coordinates of each group recorded at the time of finding, recognizing and identifying each group within the five-day period mentioned above. The home range was calculated through the Home Range extension (Rodgers and Carr 1998) of ArcView 3.2 (ESRI 1999). In order to determine the representativeness of the sample size, the cumulative area used was plotted versus time for each group (Laver and Kelly 2008). It was assessed whether the home range size was significantly related to the group factor, using monthly data (HR) for each group and applying a linear mixed model (the data were previously tested for normality). To this end, monthly replicates were set as a random factor and the group as a fixed factor. The analysis of variance of the linear mixed model was run with SPSS 20.0 (IBM 2011), with a significance of $P<0.05$.

Estimate of tree species diversity. Food resources were estimated through the diversity of tree species. The data were obtained in 10 random plots measuring $2 \times 50 \mathrm{~m}$ within the home range of each group. All trees with a diameter at breast height greater than or equal to $10 \mathrm{~cm}$ were identified. Specimens were taxonomically identified with the assistance of a botanical specialist (Santiago SinacaColin) and by consulting specimens deposited in the Xal herbarium at the Institute of Ecology, Xalapa, and the Xalu herbarium at the Universidad Veracruzana. From these data, we evaluated the tree species richness in the HR of each group. In addition, we calculated the following indices: order 1 diversity index (inverse of the Shannon index); order 2 diversity (inverse of the Simpson index), and similarity indices based on incidence and abundance, using the Spade program (Chao and Shen 2010). Order 1 diversity is adjusted for species abundance, while order 2 diversity is based on the most abundant species in the community (Moreno et al. 2011).

On the other hand, since the species of the genus Ficus (family Moraceae) have been frequently considered as a major food item in the diet of the howler monkey (Milton 1984; Serio-Silva et al. 2002; Días and Rangel-Negrin 2015), the number of individuals and the Impartance Value (IV, Coroi et al. 2004) of these species within the HR of the two groups was analyzed.

\section{Results}

Daily activity pattern and $H R$. The sampling effort was 330 observation hours for $\mathrm{G} 1$ and 402 hours for $\mathrm{G} 2$, for obtaining location records for both groups as well as for sampling the habitat ( 210 hours for $\mathrm{G} 1$ and 182 for G2); also, behavioral records were obtained ( 120 hours for G1 and 220 for G2, with 120 and 220 focal, respectively), resulting in an average of 20 hours per adult specimen.

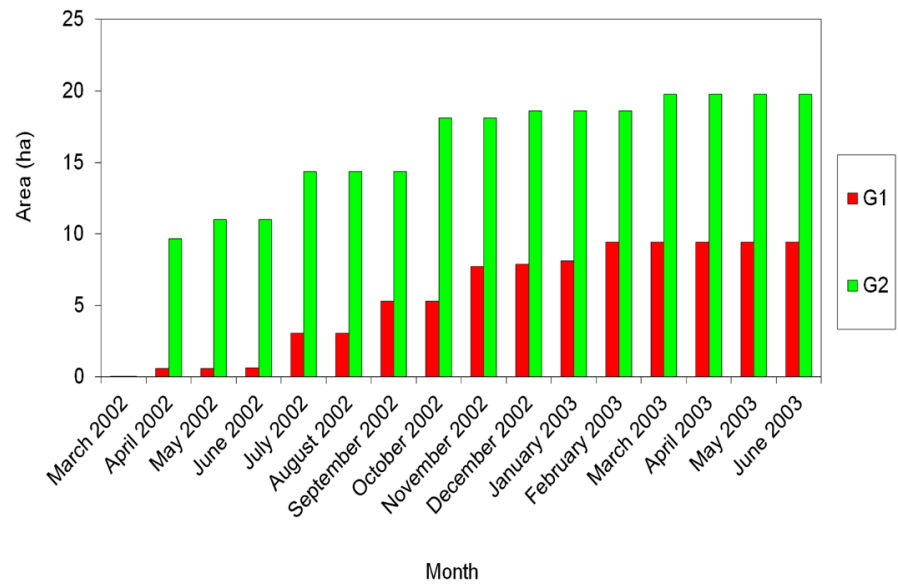

Figure 2. Cumulative area of the home range in the period March 2002 to June 2003 for two groups (G1 and G2) of the howler monkey, Alouatta palliata. The increase in the size of the area used through time reached an asymptotic behavior for both groups, in February 2003 for G1 and March 2003 for G2. 
Table 2. Indicators of tree diversity in the home range of two groups (G1 and G2) of the howler monkey, Alouatta palliata, in Veracruz, Mexico.

\begin{tabular}{|c|c|c|c|c|}
\hline Estimator & G1 & G2 & Comparison & \\
\hline \multirow[t]{2}{*}{ Exclusive Species } & 8 & 19 & Total Exclusive Species & 27 \\
\hline & & & Shared Species & 12 \\
\hline Order 1 Diversity & & & & \\
\hline Exponential of the Shannon index (MLE). & $5.31 \pm 0.91$ & $18.75 \pm 2.06$ & $\begin{array}{l}\text { Similarity Jaccard index (according } \\
\text { to incidence) }\end{array}$ & $0.29 \pm 0.05$ \\
\hline \multicolumn{5}{|l|}{ Order 2 Diversity } \\
\hline Inverse Simpson Index & $2.45 \pm 0.31$ & $12.22 \pm 0.23$ & & \\
\hline Species of the family Moraceae & 2 & 3 & & \\
\hline Importance Value Index for species of the family Moracea & 14.1 & 32.2 & & \\
\hline
\end{tabular}

The home range of neighboring groups in a patch of approximately 100 ha varied according to the estimation method used. G1 had an average home range of 8.5 ha (7.0 to 10.0 ); $G 2$, of 21.0 ha (19.7 to 23.3 ha; Table 1 ). The average HR size deffered between both groups $\left(F_{1,20}=14.45, P\right.$ $=0.001)$. The monthly home range size stabilized after 12 months for G1 and at 13 months for G2 (February and March 2003, respectively; Figure 2). An overlap between home range of both groups was detected (Figure 3) using the fixed Kernel method (4.4\%), and $100 \times 100$ m grids ( $25 \%$ ).

As regards the daily activity pattern, $\mathrm{G} 1$ recorded significantly more locomotion episodes than $\mathrm{G} 2(\mathrm{U}=38, P<0.05$; Figure 4$)$. In the case of trip, feeding, rest, and social behaviors, no significant differences were found $(P>0.05)$.

Tree species diversity and availability of Ficus spp. The total number of tree species in the habitat was 39 for the two groups. The number of tree species was higher within the HR of G2 (31 species) relative to G1 (20 species). Of the species found, G1 had eight unique tree species, while G2 had 19. The indicators of true diversity, represented by the exponential of the Shannon index (G1:5.3; G2: 18.7) and the inverse of the Simpson index (G1: 2.45; G2: 12.2; order-1 and order-2 diversity, respectively) were also higher for $\mathrm{G} 2$. The number of species shared by both groups was 12 (nearly $30 \%$ of all species). In this sense, the similarity of tree species between groups was low; the Jaccard index was 0.29 (Table 2).

The record of the species of the family Moraceae showed two species of the genus Ficus in the HR of G1 (F. maxima Mill. and F. yoponensis Desv.), and three species in the HR of G2 (F. colubrinae Standl., F. petenencis Lundell and F. yoponensis Desv.). Only one species is shared in the HR of the two groups ( $F$. yoponensis). The importance value index of these Ficus species (in relation to the tree species found in each HR separately) was as follows: G1, F. maxima Mill: 17.2, F. yoponensis Desv: 10.9; G2, F. colubrinae Standl: 49.0, F. petenencis Lundell: 27.4, and F. yoponensis Desv: 20.3. Average Importance Value Index values for the family Moraceae in each HR were 14.1 for $\mathrm{G} 1$ and 32.2 for $\mathrm{G} 2$.

\section{Discussion}

Home Range estimates are within the range reported for $A$. palliata by Dunn et al. (2009); these authors obtained variations of HR between 5.8 and 89.5 ha (in habitats with areas of 7.2 ha and 244 ha, respectively). On the other hand, the grid method $(100 \times 100 \mathrm{~m})$ estimated a maximum HR of 21 ha, that is, one third of the area estimated by Estrada (1984) also in the Los Tuxtlas region and using the same method (60 ha). The greatest similarity in the comparison of methods with other works conducted in the same area occurred with the Minimum Convex Polygon method (PMC), which yielded 9.4 ha for $\mathrm{G} 1$ and 19.7 ha for $\mathrm{G} 2$. These data are equivalent to those reported for A. palliata by CristobalAzkarate and Arroyo-Rodríguez (2007), who estimated 14.7 ha. On the other hand, Colias and Southwick (1952) in a continuous habitat in Barro Colorado, Panama, and Williams-Guillen et al. (2006) in a fragmented habitat in Nicaragua, estimated the HR for A. palliata using PMC; their estimates did not exceed 35 ha for groups of 15 individuals.

There are multiple factors that influence home range size. Our results support the hypothesis proposed by Seth and Seth (1986), who suggest that a large HR generally involves higher richness and diversity of both plant species and food resources. Among the explanations of the variation in the home range of A. palliata, HR size is suggested to be associated with the amount of habitat available (Cristobal-Azkarate and Arroyo-Rodríguez 2007). In the present study, the largest group that displayed the largest number of adult males and females had a larger HR coupled with the highest richness of tree species. The increase in group
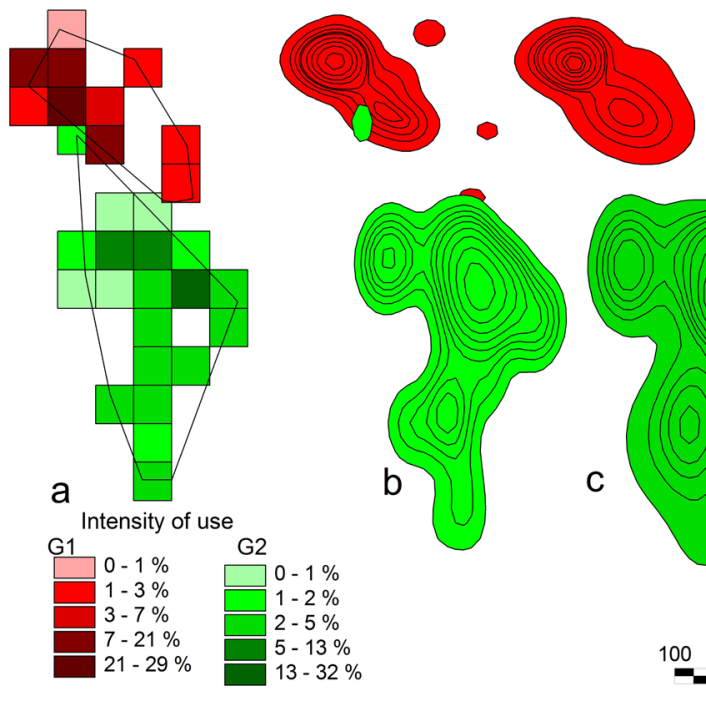

G1

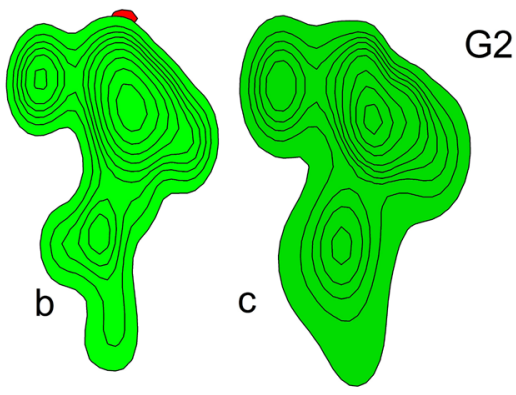

Figure 3. Shape and size of the home ranges of each group (G1 and $\mathrm{G} 2$ ) of the howler monkey, Alouatta palliata. 3a) Minimum convex polygon and $100 \times 100$ m grids 3b) Fixed Kernel method; 3c) Adapted Kernel method. Overlap was detected between the groups using the $100 \times 100$ m grid method $(25 \%)$ and the fixed Kernel method (4.4\%). The color intensity in the grid method corresponds to the relative frequency of occupation calculated using the extension of ArcView 3.2. 


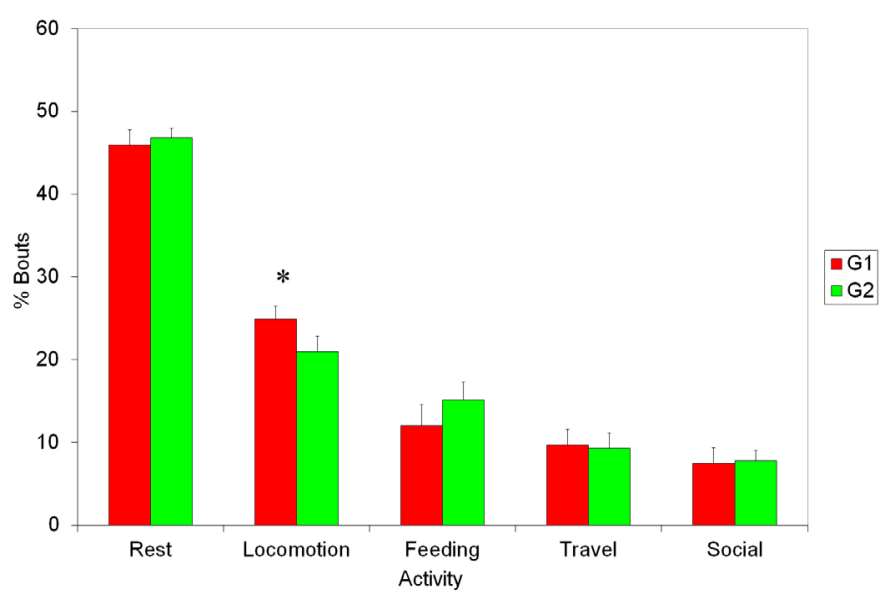

Figure 4. Comparison of behaviors observed in each group (G1 and G2) of the howler monkey, Alouatta palliata. Only the locomotion behavior showed significant differences between the two groups.

size also involves higher costs. In this regard, Chapman et al. (1995) have suggested that a larger group of monkeys leads to a faster depletion of resources and, therefore, results in the need to move to other sites in search for food. In that sense, the largest group of monkeys was $\mathrm{G} 2$, which corresponds to the largest HR having the highest richness of tree species. However, its locomotion episodes were fewer than those of G1, which displayed smaller group size and $\mathrm{HR}$. It has been mentioned that the cost associated with search for food increases along with the increase in group size (Chapman and Chapman 2000; Chapman and Pavelka 2005; Robbins et al. 2009); the greater locomotion recorded in $\mathrm{G} 1$ is likely related to the lower habitat richness, which promotes a more intense search for food resources. In this regard, Dunn et al. (2009) consider that some changes in the locomotion of the howler monkey result from the lower availability of trees and fruits. In addition, Rodríguez-Luna et al. (2003) reported a relationship between larger displacement and lower time spent foraging; in addition, they point to the incorporation of new species to the diet when the density of howler monkeys increased considerably.

In the present study, the larger group size coupled with the larger number of males in G2 resulted in the appropriation of patches with the greatest availability of food resources. In this regard, Van-Schaik and Kappeler (1993) point out that the more richness and abundance of food resources there is, the greater the size of the group. As a result, males will be more efficient in competing and defending these resources against a neighboring group. In this work, the habitat of G2 had an Importance Value Index of more than twice the figure obtained for the habitat of G1 regarding the species of Ficus sp., as well as a higher percentage of trees ( $26.1 \%$ for $\mathrm{G} 2$ versus $14.2 \%$ for $\mathrm{G} 1$ ). The species in this family are considered as key in the diet of the howler monkey; the time spent by A. palliata mexicana foraging on Ficus trees ranges between $14 \%$ and 48 \% (Estrada 1984; Serio-Silva et al. 2002; Rodríguez-Luna et al. 2003; Asencio et al. 2007; Cristobal-Azkarate and ArroyoRodríguez 2007). In this regard, the presence of trees of the
Moraceae family suggests a favorable aspect for the two groups. In an adjacent area covered by a continuous forest, Estrada (1984) reported a relative density of 32.4 trees/ ha belonging to that family. However, although a density of only 1.4 trees/ha was reported for Ficus spp., the A. palliata individuals observed devoted a greater percentage of their time feeding on Ficus trees. Therefore, the opportunities of G2 to feed on Ficus trees were nearly twice as large as those of G1. This suggests that the groups studied use sites where, in proportion to their size, there are sufficient resources for both groups without the need to invade areas outside their home ranges.

This could explain the reduced HR overlap and the absence of agonistic behavior observed between $\mathrm{G} 1$ and G2. Theoretically, under these circumstances, there is an indirect exploitation competition, i. e., a low intergroup tolerance coupled with a differential use of resources; hence, most of the time there is no aggressive competition between the groups (Nicholson 1954; Wrangham et al. 1993). Although the species A. palliata shows wounds and scars from injuries associated with agonistic behaviors (Cristobal-Azkarate et al. 2004), it has been found that the groups of this species remain relatively separated from one another (Hopkins 2013), which reduces the possibility of intergroup aggressions.

Of all the methods used to measure HR, only the 100-m grid and the Kernel methods suggested some degree of overlap, $25 \%$ and $4.4 \%$, respectively. These figures are similar to those by Mittermeier (1973), who reported an average $8.5 \%$ overlap between neighboring A. palliata groups; and those by Williams-Guillen et al. (2006), who recorded a maximum overlap of $7 \%$ between three groups; this figure was estimated with the PMC method. A. caraya is characterized by a high overlap between groups (94\% overlap), which contrasts with our findings (Baldwin and Baldwin 1972).

The results revealed information consistent with the ecological restriction model proposed by Chapman et al. (1995). It was recorded that the largest group inhabits the site with the greatest tree species richness within the largest HR. The intergroup dynamics of neighboring howler monkey groups in a fragmented habitat shows a small HR overlap. Although competition takes place, it seems to be of the indirect type, where the most important food resources (Ficus trees) show differences in abundance within the home ranges of the two groups; no direct aggression of any sort was observed. It is essential to advance the investigations on intergroup dynamics in the genus Alouatta to characterize the coexistence strategies between neighboring groups in sites subjected to different degrees of disturbance and different areas of activity. This will contribute to better understand the variability in the use of space by howler monkeys.

\section{Acknowledgments}

This research work was undertaken with financial support granted to the firth author by the Consejo Nacional de Ciencia y Tecnología (registration number 170666). We 
thank the logistic support and the efforts made by D. Canales Espinosa and E. Rodríguez Luna for the conduct of the research activities in Montepío, Veracruz; also, we appreciate the comments from our two reviewers, which contributed to improve the manuscript. María Elena Sánchez-Salazar translated the manuscript into English.

\section{Cited literature}

Altmann, J. 1974. Observational study of behavior: sampling methods. Behaviour 49:227-267.

AmsLeR, S. J. 2010. Energetics costs of territorial boundary patrols by wild chimpanzees. American Journal of Primatology 72:93-103.

Asencio, N., J. Cristóbal-Azkarate, P. A. Duarte-Dias, J. J. Véa, and E. Rodriguez-LunA. 2007. Foraging habits of Alouatta palliata mexicana in three forest fragments. Folia Primatologica 78:141-153.

BALDWIN, J. D., AND J. I. BaLDWIN. 1972. Population density and use of space in howling monkeys (Alouatta villosa) in southwestern Panama. Primates 13:371-379.

BöRGER, L., B. D. DAlzIEL, AND J. M. FryXelL. 2008. Are there general mechanisms of animal home range behaviour? A review and prospects for future research. Ecology Letters 11:637-650.

Campera, M., V. Serra, M. Balestri, M. Barresi, M. Ravaolahy, F. RANDRIATAFIKA, AND G. DonAtI. 2014. Effects of Habitat Quality and Seasonality on Ranging Patterns of Collared Brown Lemur (Eulemur collaris) in Littoral Forest Fragments. International Journal of Primatology 35:957-975.

Campos, F. A., M. L. Bergstrom, A. Childers, J. D. Hogan, K. M. Jack, A. D. Melin, K. N. Mosdossy, M. S. Myers, N. A. Parr, E. Sargeant, V. A. M. Schoof, AND L. M. Fedigan. 2014. Drivers of home range characteristics across spatiotemporal scales in a Neotropical primate, Cebus capucinus. Animal Behaviour 91:93-109.

Castillo-Campos, G., and J. Laborde. 2004. La vegetación. Pp. 231-265, in Los Tuxtlas: El paisaje de la sierra (Guevara, S. J., J. Laborde, and G. Sánchez-Ríos, eds.). Instituto de Ecología/ Unión Europea. Xalapa, México.

ChAo, A., AND T. J. Shen. 2010. SPADE (Species prediction and diversity estimation) v6 Program distributed by the author. Institute of Statistics. National Tsing Hua University. HsinChu, Taiwan.

Chapman, C. A., And L. J. Chapman. 2000. Determinants of group size in primates: The importance of travel cost. Pp. 24-42, in On the move, how and why animals travel in groups (Boinski, S. y P. A. Garber, eds.). Universidad de Chicago. Chicago, U. S. A. Chapman, C. A., R. W. Wrangham, and L. J. Chapman. 1995. Ecological constraints on group size: An analysis of spider monkey and chimpanzee subgroups. Behavioral Ecology and Sociobiology 36:59-70.

Chapman, C.A., And M. S. Pavelka. 2005. Group size in folivorous primates: ecological constraints and the possible influence of social factors. Primates 46:1-9.

CLARKE, M.R. 1990. Behavioral development and socialization of infants in a free-ranging group of howling monkeys (Alouatta palliata). Folia Primatologica 54:1-15.

Colias, N. E., AND C. SOUTHWICK. 1952. A Field study of population density and social organization in howling monkeys. Proceedings of the American Philosophical Society 96:143-156.
Corol, M., M. Sheehy-Skeffington, P. Giller, C. Smith, M. Gormally, And G. O'Donovan. 2004. Vegetation diversity and stand structure in streamside forests in the south of Ireland. Forest Ecology and Management 202:39-57.

Cristóbal-Azkarate, J., P. A. D. Dias, and J. J. Veà. 2004. Causes of intraspecific aggression in Alouatta palliata mexicana: Evidence from injuries, demography, and habitat. International Journal of Primatology 25: 939-953.

Cristóbal-Azkarate, J., and V. Arroyo-Rodriguez. 2007. Diet and activity pattern of howler monkeys (Alouatta palliata) in Los Tuxtlas, Mexico: Effects of habitat fragmentation and implications for conservation. American Journal of Primatology 69:1013-1029.

Dias, P.A., AND A. Rangel-Negrín. 2015. Diets of howler monkeys. Pp. 21-56, in Howler monkeys behavior, ecology, and conservation developments in primatology: Progress and prospects vol. 2 (Kowalewski, M. M., P. A. Garber, L. CortésOrtiz, B. Urbani, and D. Youlatos, eds.). Springer. New York, U.S.A.

Domingo-Balcells, C., and J. J. Véa-Baró. 2009. Developmental stages in the howler monkey, subspecies Alouatta palliata mexicana: a new classification using age-sex categories. Neotropical Primates 16:1-8.

Dunn, J. C., J. Cristóbal-Azkarate, and J. Veà. 2009. Differences in diet and activity pattern between two groups of Alouatta palliata associated with the availability of big trees and fruit of top food taxa. American Journal of Primatology 71:654-662.

EsRI. 1999. ArcView v3.2 para Windows. Environmental Systems Research Institute. California, U. S. A.

EstRADA, A. 1984. Resource use by howler monkeys (Alouatta palliata) in the rain forest of Los Tuxtlas, Veracruz, Mexico. International Journal of Primatology 5:105-131.

GlessneR, K. D. G., AND A. BRITT. 2005. Population density and home range size of Indri indri in a protected low altitude rain forest. International Journal of Primatology 26:855-872.

HopKINS, M. E. 2013. Relative dominance and resource availability mediate mantled howler (Alouatta palliata) spatial responses to neighbors' loud calls. International Journal of Primatology 34:1032-1054.

IBM CoRP. ReLEASED. 2011. IBM SPSS Statistics para Windows v20.0. Nueva York, U. S. A.

Kernohan, B. J., R. A. Gitzen, and J. J. Millspaugh. 2001. Analysis of animal space use and movements. Pp. 125-166, in Radio tracking and animal populations (Millspaugh, J. J., and J. M. Marzluff, eds.). Academic. San Diego, U. S. A.

Kodric-Brown, A., AND J. H. Brown. 1978. Influence of economics, interspecific competition, and sexual dimorphism on territoriality of migrant rufous hummingbirds. Ecology 59:285-296.

LAVER, P. N., AND M. J. KelLy. 2008. A critical review of home range studies. The Journal of Wildlife Management 72:209-298.

Lopez-Darias, M., T. W. Schoener, D. A. Spiller, and J. B. Losos. 2012. Predators determine how weather affects the spatial niche of lizard prey: exploring niche dynamics at a fine scale. Ecology 93:2512-2518.

Martin, P., AND P. Bateson. 1993. Measuring behavior: An introductory guide. Universidad de Cambridge. Cambridge, United Kindom.

MendozA, E., J. Fay, AND R. Dirzo. 2005. A quantitative analysis 
of forest fragmentation in Los Tuxtlas, southeast Mexico: patterns and implications for conservation. Revista Chilena de Historia Natural 78:451-467.

MILTON, K. 1980. The foraging strategy of howler monkeys: A study in primate economics. Universidad de Columbia. Nueva York, U. S. A.

Mıton, K. 1984. Habitat, diet and activity patterns of free-ranging woolly spider monkeys (Brachyteles arachnoides E. Geoffroy 1806). International Journal of Primatology 5:491-514.

Mittermeier, R. 1973. Group activity and population dynamics of the howler monkeys of Barro Colorado Island. Primates 14:1-19.

Moreno, C. E., F. Barragán-Pavón, E. Pineda, and N. P. Pavón. 2011. Reanálisis de la diversidad alfa: alternativas para interpretar y comparar información sobre comunidades ecológicas. Revista Mexicana de Biodiversidad 82:1249-1261.

Nicholson, A. J. 1954. An outline of the dynamics of animal populations. Australian Journal of Zoology 2:9-65.

Pearce, F., C. Carbone, G. Cowlishaw, and N. J. B. Isaac. 2013. Spaceuse scaling and home range overlap in primates. Proceedings of the Royal Society B 280:1-6.

Pebsworth, P. A., A. J. J. Maclntosh, H. R. Morgan, and M. A. Huffman. 2012. Factors Influencing the ranging behavior of chacma baboons (Papio hamadryas ursinus) living in a humanmodified habitat. International Journal of Primatology 33:872-887.

Pyritz, L. W., P. M. Kappeler, and C. Fichtel. 2011. Coordination of group movements in wild red-fronted lemurs (Eulemur rufifrons): processes and influence of ecological and reproductive seasonality. International Journal of Primatology 32:1325-1347.

Robbins, A. M., T. S. Stoinski, K. A. Fawcett, and M. M. Robbins. 2009. Socioecological influences on the dispersal of female mountain gorillas, evidence of a second folivore paradox. Behavioral Ecology and Sociobiology 63:477-489.

Rodgers, A. R., and A. P. Carr. 1998. HRE: The Home Range Extension for ArcView. Program distributed by the author. Ministry of Natural Resources. Centre for Northern Forest Ecosystem Research. Ontario, Canadá.

Rodríguez-Luna, E., L. E. Domínguez-Domínguez, J. E. Morales-Mávil, AND M. Martínez-Morales. 2003. Foraging strategy changes in an Alouatta palliata mexicana troop released on an island. Pp. 229250, in Primates in fragments: Ecology and conservation (Marsh, L. K., ed.). Kluwer Academic/ Plenum. Nueva York, U. S. A.

Serio-Silva, J. C., V. Rico-Gray, L. T. Hernández-Salazar, and R. EsPINOSA-Gómez. 2002. The role of Ficus (Moraceae) in the diet and nutrition of a troop of Mexican howler monkeys, Alouatta palliata mexicana, released on an island in southern Veracruz, Mexico. Journal of Tropical Ecology 18:1-16.

Seth, P. K., And S. Seth. 1986. Ecology and behaviour of rhesus monkeys in India. Pp. 89-104, in Primate ecology and conservation (Else, J. G., and P. C. Lee, eds.). Universidad de Cambridge. Cambridge, United Kindom.

SHAFFER, C. A. 2014. Spatial Foraging in Free Ranging Bearded Sakis: Traveling Salesmen or Lévy Walkers? American Journal of Primatology 76:472-484.

Solórzano-García, B., E. A. Ellis, and E. Rodríguez-Luna. 2012. Deforestation and primate habitat availability in Los Tuxtlas Biosphere Reserve, Mexico. International Journal of
Ecosystem 2:61-66.

Sото, M. 2004. El clima. Pp.195-200, in Los Tuxtlas, el paisaje de la sierra (Guevara, S. J., J. Laborde, and G. Sánchez-Ríos, eds.). Instituto de Ecología/Unión Europea. Xalapa, México.

VAN-SChaIK, C. P., AND P. M. Kappeler. 1993. Life history, activity period and lemur social systems. Pp. 241-260, in Lemur social systems and their ecological basis (Kappeler, P. M., and J. U. Ganzhorn, eds.). Plenum. New York, U. S. A.

Williams-Guillén, K., C. McCann, J. C. Martínez-Sánchez, and F. KoonTz. 2006. Resource availability and habitat use by mantled howling monkeys in a Nicaraguan coffee plantation: can agroforests serve as core habitat for a forest mammal? Animal Conservation 9:331-338.

Worton, B. J. 1989. Kernel methods for estimating the utilization distribution in home-range studies. Ecology 70:164-168.

Wrangham, R.W., G. L. Gittleman, and C. A. Chapman. 1993. Constraints on group size in primates and carnivores: population density and day-range as assays of exploitation competition. Behavioral Ecology and Sociobiology 32:199-209.

Associated editor: Consuelo Lorenzo

Submitted: November 20, 2016; Reviewed: January 13, 2017;

Accepted: February 14, 2017; Published on line:March 12, 2017. 
98 THERYA Vol. 8(2): 91-97 